\title{
EKSTRAK COCOR BEBEK TERHADAP KADAR TNF- $\alpha$ PADA PLASENTA, TEKANAN DARAH, ALBUMIN URINE PADA LUPUS BUNTING
}

\author{
Sofia Mawaddah ${ }^{\bowtie}$ \\ Jurusan Kebidanan Poltekkes Kemenkes Palangka Raya
}

\begin{tabular}{l} 
ARTICLE INFO \\
\hline Article history
\end{tabular}

Submitted : 2019-01-09

Revised : 2019-02-22

Accepted : 2019-12-17

Keywords:
Cocor duck extract
Lupus

\section{Kata Kunci:}

Ekstrak cocor bebek Lupus

\begin{abstract}
Cocor duck plants contain alkaloids, flavonoids, phenolic compounds, tannins, vitamins, macro and micro elements, lemon acid, apple acid, vitamin C, quercetin-3diarabenoside and kaemferol-3-glucoside. Inside the duck duck, there is a flavonoid which is a natural phenolic compound which has potential as an antioxidant and has bioactivity as a medicine or as an herbal medicine to treat LES. The aim of the study was to determine the effect of duck cocor extract on TNF- $\alpha$ levels in the placenta, blood pressure and urine albumin in the Balb/c lupus pregnant mice model. Female BALB/c mice were injected pristan $0.5 \mathrm{ml}$, after 12 weeks of ANA examination, if the test was positive then the mice were pregnant. Pregnant lupus mice were given Coco Duck extract in three different doses: $10.5 \mathrm{mg} /$ day, $21 \mathrm{mg} /$ day and $42 \mathrm{mg}$ /day orally every day for 10 days of pregnancy. The percentage of TNF- $\alpha$ was examined by the ELISA method, MAP was examined using COD and urine albumin was examined by the ELISA method. The results of the study are there are effects of giving cocor duck extract on TNF- $\alpha$ levels. Doses of $10.5 \mathrm{mg} /$ day and $42 \mathrm{mg} /$ day have the ability to reduce TNF- $\alpha$ levels. Meanwhile, in blood pressure and urine albumin, Cocor Duck extract was not able to reduce significantly. Cocor duck leaf extract can significantly reduce TNF- $\alpha$ levels. Cocor duck leaf extract is unable to reduce urine albumin levels and blood pressure. The remedy for dealing with LES is very limited, therefore extra cocor duck leaves can be used as an alternative treatment for LES.
\end{abstract}

\begin{abstract}
Tanaman cocor bebek mengandung alkaloid, flavonoid, senyawa fenolik, tanin, vitamin, makro dan mikro elemen, zat asam lemon, zat asam apel, vitamin $\mathrm{C}$, quercetin-3diarabenoside dan kaemferol-3-glukoside. Di dalam cocor bebek terdapat flavonoid yang termasuk senyawa fenolik alam yang potensial sebagai antioksidan dan mempunyai bioaktivitas sebagai obat atau sebagai obat herbal untuk mengatasi penyakit LES. Tujuan penelitian mengetahui pengaruh ekstrak cocor bebek terhadap kadar TNF$\alpha$ pada plasenta, tekanan darah dan albumin urine pada model mencit Balb/c lupus bunting. Mencit Balb/c betina diinjeksi pristan 0,5 ml, setelah 12 minggu dilakukan pemeriksaan ANA, jika tes positif maka mencit dibuntingkan. Mencit lupus bunting diberi ekstrak cocor bebek dengan tiga dosis yang berbeda: $10,5 \mathrm{mg} / \mathrm{hari}, 21 \mathrm{mg} / \mathrm{hari}$ dan $42 \mathrm{mg} /$ hari secara oral setiap hari selama 10 hari masa kehamilan. Persentase TNF$\alpha$ diperiksa dengan metode ELISA, MAP diperiksa dengan menggunakan COD dan albumin urin diperiksa dengan metode ELISA. Hasil penelitian yaitu ada pengaruh pemberian ekstrak cocor bebek terhadap kadar TNF- $\alpha$. Dosis $10,5 \mathrm{mg} /$ hari dan 42 $\mathrm{mg} /$ hari mempunyai kemampuan terhadap penurunan kadar TNF- $\alpha$. Pada tekanan darah dan albumin urin, ekstrak cocor bebek tidak mampu menurunkan secara signifikan. Ekstrak daun cocor bebek mampu menurunkan kadar TNF- $\alpha$ secara signifikan. Ekstrak daun cocor bebek tidak mampu menurunkan kadar albumin urin dan tekanan darah. Obat untuk mengatasi penyakit LES sangat terbatas, oleh karena itu ekstra daun cocor bebek dapat dioalh sebagai salah satu alternatif pengobatan penyakit LES.
\end{abstract}

$\triangle$ Corresponding Author:

Sofia Mawaddah

Jurusan Kebidanan Poltekkes Kemenkes Palangka Raya

Telp. 082251474861

Email: sofizline@gmail.com

\section{PENDAHULUAN}

Terganggunya mekanisme pengaturan imun seperti eliminasi dari sel-sel imun yang mengalami apoptosis dan penumpukan kompleks imun berperan penting terhadap terjadinya LES. Penumpukan kompleks imun di jaringan dapat mengakibatkan terjadinya inflamasi yang dapat mengakibatkan terjadinya kerusakan jaringan. Inflamsi dapat lokal, 
sistemik, akut dan kronis (Baratawijaya \& Rengganis, 2014).

Penderita LES didominasi oleh wanita usia reproduktif dibandingkan pria dengan rasio 9:1. Hal ini disebabkan karena pengaruh hormon seks wanita terhadap aspek sistem imun tubuh. Hormon seks wanita yaitu estrogen dapat memfasilitasi respon humoral yang menyebabkan terjadinya peningkatan proliferasi dan produksi sel B. Estrogen dengan kosentrasi tinggi akan menghambat respon sel $\mathrm{T}$, seperti proliferasi produksi IL-2. Hal ini menunjukkan bahwa sel T lebih sensitif terhadap estrogen. Estrogen dapat memperburuk kondisi pasien LES dengan memperpanjang kelangsungan hidup dari selsel autoimun, meningkatkan sel Th2 dan merangsang sel $\mathrm{B}$ untuk memproduksi autoantibodi. Penghambatan respon Th1 dan peningkatan ekspresi CD40 pada sel T lupus menyebabkan peningkatan Th2 dan mengakibatkan sel B menjadi hiperaktif (Josephine, 2014).

Sistemik Lupus Eritematosus adalah penyakit kronis pada system autoimun yang terjadi terutama pada wanita usia subur. Semua kehamilan dengan wanita yang menderita LES dianggap sebagai kehamilan dengan resiko tinggi. Terlebih lagi, kehamilan dapat meyebabkan flare (kekambuhan) aktivitas penyakit lupus (Josephine, 2014). Sekitar 75\% kehamilan mencapai masa kelahiran, 25\% diantaranya prematur, $25 \%$ sisanya mengalami keguguran. Resiko keguguran lebih tinggi pada wanita dengan antibodi antifosfolipid, penyakit ginjal aktif atau hipertensi, atau kombinasi lainnya. Selama kehamilan antibodi antifosfolipid dapat melintasi plasenta dan menyebabkan trombositopenia pada janin, namun biasanya bayi tetap dapat lahir dengan aman.

Prognosa ibu hamil yang menderita LES ditentukan pada saat konsepsi, bila konsepsi terjadi pada masa remisi maka prognosanya akan lebih baik. Penderita LES yang telah mengalami masa remisi lebih dari 6 bulan sebelum masa kehamilannya mempunyai resiko kambuh (eksaserbasi) $25 \%$ pada masa kehamilan dibandingkan dengan masa remisi LES sebelum hamil kurang dari 6 bulan yaitu menjadi $50 \%$ dan memperburuk kondisi kehamilan.

Autoantibodi yang terbentuk pada ibu yang menderita LES dapat memberikan dampak yang buruk pada plasenta dan janin sehingga dapat berakhir dengan kegagalan kehamilan (Varghese et al, 2011). Komplikasi umum pada kehamilan yang sering terjadi pada wanita yang menderita LES ialah adanya faktor prediktor diantaranya hipertensi, preeklamsi, eklamsi, perdarahan anterpartum, IUGR, prematuritas, abortus dan still birth serta diabetes dalam kehamilan (Varghese et $a l, 2015)$.

Kondisi penyakit LES yang buruk pada wanita hamil akan mengakibatkan terjadinya flare pada kehamilan sehingga dapat berpengaruh terhadap kondisi ibu maupun janin. Flare ialah kekambuhan atau serangan yang tidak terduga dari penyakit setelah periode remisi. Flare pada penyakit LES pada kehamilan merupakan prediktor yang sangat kuat berhubungan dengan dampak buruk yang terjadi selama kehamilan seperti pengakhiran kehamilan, kelahiran prematur dan Intrauterine Growth Retardation (IUGR). Ibu hamil dengan LES mempunyai risiko tinggi terjadi Preeklamsi. Komplikasi yang terjadi pada ibu dan janin adalah stroke, kelahiran prematur, bahkan kematian (Arfaj \& Khail, 2014).

\section{METODE PENELITIAN}

\section{Jenis Penelitian}

Jenis penelitian yang digunakan adalah True Experimental (Eksperimen sesungguhnya) dengan pendekatan Post Test Only Control Group Desain.

\section{Lokasi dan Waktu Penelitian}

Penelitian ini berlokasi di Universitas Brawijaya Malang (UB) dan RS dr. Soetomo Surabaya. Penelitian dilaksanakan pada bulan Mei - Oktober tahun 2015.

\section{Populasi dan Sampel}

Populasi penelitian adalah mencit Balb/c lupus betina. Jumlah sampel pada penelitian ini yaitu 25 mencit galur Balb/c.

Kriteria inklusi subjek penelitian adalah Mencit galur Balb/c bunting, umur 2628 minggu. Kriteria eksklusi adalah Mencit mati setelah injeksi pristan sebelum dibuntingkan.

\section{Pengumpulan Data}

Peneliti menggunakan hewan percobaan dengan proses sebagai berikut. 
Hewan percobaan yang digunakan adalah mencit bunting galur BALB/c betina yang (2025 gr) usia 10 - 12 minggu sejumlah 20 ekor yang diperoleh dari LPPT Universitas Islam Negeri (UIN) Malang, mencit dikelompokkan menjadi 5 kelompok:

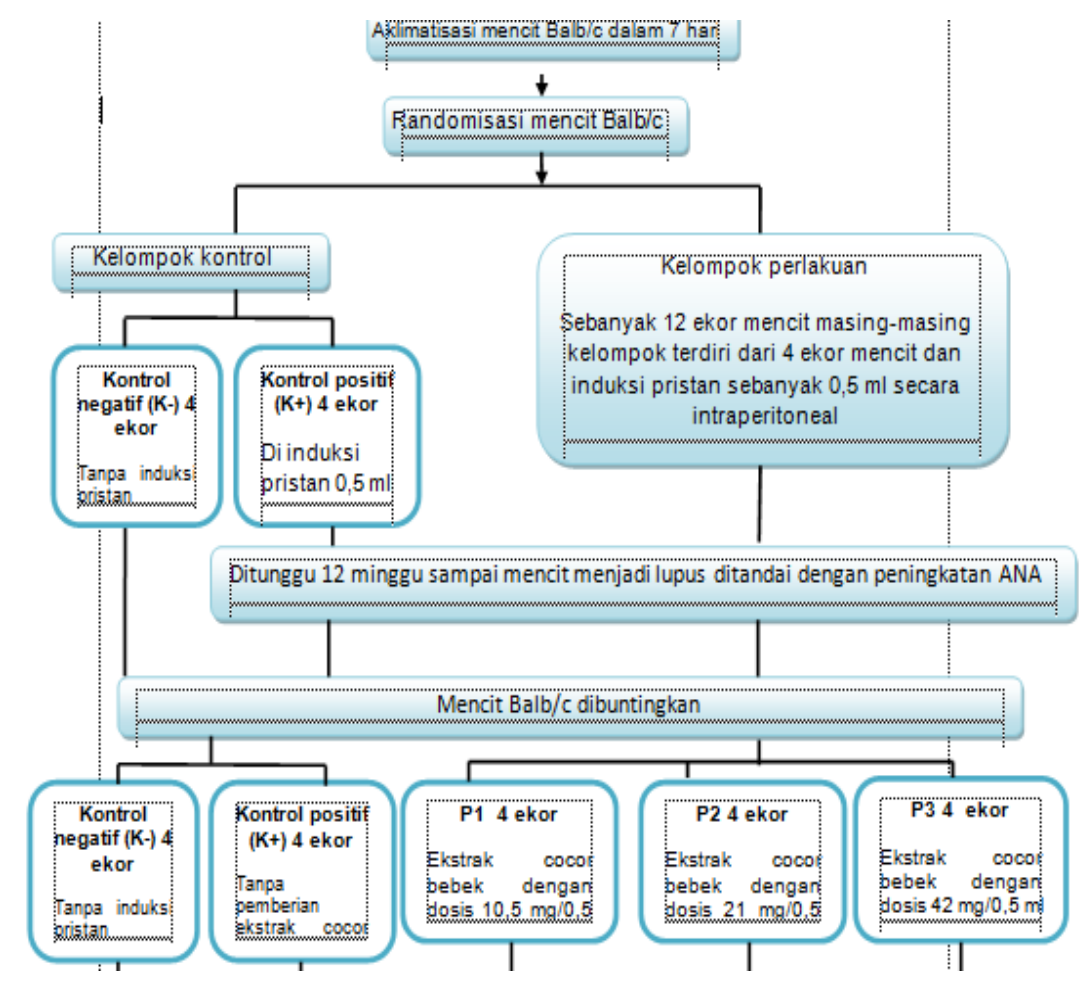

Kelompok kontrol negatif (mencit bunting sehat), kelompok kontrol positif (mencit bunting lupus), kelompok perlakuan I (mencit bunting lupus + ekstrak cocor bebek dosis $10,5 \mathrm{mg} /$ hari), kelompok perlakuan II (mencit bunting lupus + ekstrak cocor bebek dosis $21 \mathrm{mg} /$ hari) dan kelompok perlakuan III (mencit bunting lupus + ekstak cocor bebek dosis $42 \mathrm{mg} /$ hari). Mencit di adaptasi selama 7 hari, kemudian diinjeksi Pristan 0,5 mg setelah lebih dari 12 minggu dan mempunyai hasil tes ANA yang positif maka mencit dibuntingkan. Pada hari ke 9 gestasi mencit diberi ekstrak daun cocor bebek.

Pembuatan mencit model lupus dilakukan dengan cara menyuntikan Pristan 0,5 $\mathrm{ml}$ secara intraperitonal satu kali selama penelitian dan dilakukan setelah masa aklimasi selesai yaitu setelah hari ke 7. Proses pembuntingan dilakukan 3 tahap: LeeBoot Effect, Pheromon Effect dan Whitten Effect. Mencit dikawinkan dengan mencit jantan dengan perbandingan 2 mencit betina dan 1 mencit jantan selama 1 malam. Plug vagina di periksa pada pagi hari. Betina yang menunjukkan plug vagina positif (VP+) segera dipisahkan dengan jantan. Hari terlihatnya
$\mathrm{VP}+$ dianggap sebagai hari ke 1 gestasi (Tanko, 2014).

Daun cocor bebek kering diperoleh dari UPT Materia Medika Batu Malang. Daun kering cocor bebek diproses dengan metode maserasi dengan pelarut Etanol 96\% (Miyake, 2011) di laboratorium farmakologi FKUB. Hasil ekstraksi berupa esktrak kental (pasta) dan di encerkan dengan normal saline. Metode maserasi adalah proses mengekstrak menggunakan pelarut dengan beberapa kali pengocokan atau pengadukan pada suhu kamar (Bahua, et al, 2011).

Ekstrak cocor bebek yang telah diencerkan diberikan secara oral dengan sonde khusus selama 10 hari/masa kehamilan mencit dengan dosis 10,5 mg/hari, $21 \mathrm{mg} / \mathrm{hari}, 42$ $\mathrm{mg} / \mathrm{hari}$ (Yu et al, 2018). Pengukuran kadar TNF- $\alpha$ dilakukan menggunakan metode ELISA (LEGEND MAX TM ELISA kit with pre-coated plates, Mouse TNF- $\alpha$ cat. No 430907) dan hasil ukur menggunakan ratio dengan satuan $\mathrm{pg} / \mathrm{Ml}$.

Pengukuran tekanan darah menggunakan alat Kent Scientific CODA. Pengukuran tekanan darah dihitung dengan cara menghitung rata-rata tekanan darah 
sistolik lalu dibandingkan dengan rata-rata dari kelompok kontrol (Ryan et al, 2016). Pengukuran Albumin Urin menggunakan ELISA (Elabscience, USA, nomor katalog EEL-M0656).

\section{Pengolahan dan Analisis Data}

Semua data dihitung mean \pm SD. Data diuji normalitas, dilanjutkan uji statistik menggunakan uji one way annova.

\section{HASIL PENELITIAN}

Berdasarkan gambar 1 diketahui kadar TNF- $\alpha$ yang terbentuk pada plasenta mencit Balb/c lupus bunting rata-rata TNF- $\alpha$ yang dihasilkan oleh kelompok mencit lupus bunting paling tinggi terdapat pada kelompok kontrol positif dengan rerata sebesar $21.175 \pm$ 2.368, diikuti oleh kelompok perlakuan pemberian ekstrak cocor bebek dosis $21 \mathrm{mg}$ dengan rerata $18.333 \pm 1.106$. Kemudian, kelompok perlakuan pemberian ekstrak cocor bebek dosis $10.5 \mathrm{mg}$ dengan rerata sebesar $17.167 \pm 0.751$. Selanjutnya, kelompok mencit bunting sehat dengan rerata sebesar $15.975 \pm$ 3.223 dan paling rendah persentase TNF- $\alpha$ sebesar $13.067 \pm 0.551$ dihasilkan oleh kelompok mencit lupus bunting diberi ekstrak cocor bebek dosis $42 \mathrm{mg}$.

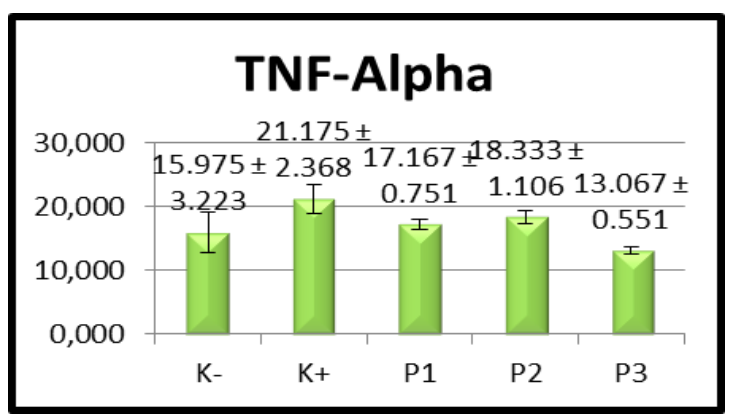

\section{Gambar 1. Rata-Rata TNF- $\alpha$ pada Mencit Balb/c Lupus Bunting berdasarkan Pemberian Esktrak Cocor Bebek}

Berdasarkan gambar 2 diketahui ratarata tekanan darah yang dihasilkan oleh kelompok mencit lupus bunting tanpa pemberian ekstrak cocor bebek paling tinggi sebesar $103.5 \pm 22.782$. Kemudian, paling tinggi kedua adalah kelompok mencit lupus bunting diberi ekstrak cocor bebek dosis $42 \mathrm{mg}$ menghasilkan rata-rata tekanan darah sebesar $88.333 \pm 9.238$. Kemudian, paling tinggi ketiga adalah kelompok mencit lupus bunting diberi ekstrak cocor bebek dosis $10.5 \mathrm{mg}$ menghasilkan rata-rata tekanan darah sebesar $84 \pm 13$. Selanjutnya, tekanan darah sebesar $81.667 \pm 15.308$ dihasilkan kelompok mencit lupus bunting diberi ekstrak cocor bebek dosis $21 \mathrm{mg}$ dan yang paling rendah persentase tekanan darah yaitu dihasilkan oleh kelompok mencit bunting sehat sebesar $69.250 \pm 5.852$.

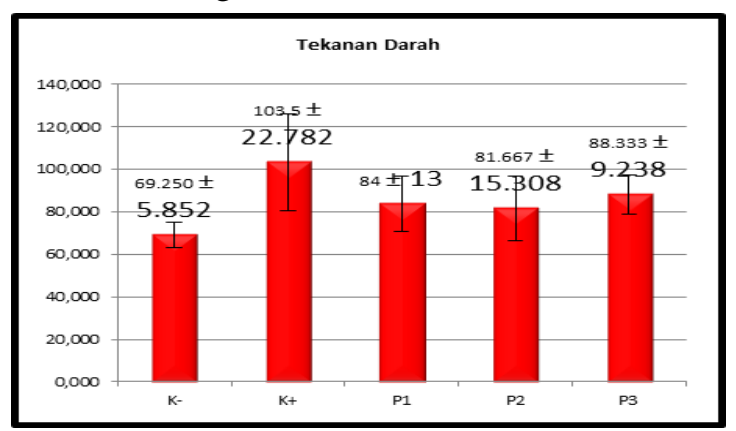

Gambar 2. Rata-Rata Tekanan Darah Pada Mencit Balb/c Lupus Bunting Berdasarkan Pemberian Ekstrak Cocor Bebek

Berdasarkan tabel 1. Diketahui terdapat perbedan pengaruh yang signifikan pemberian ekstrak cocor bebek pada mencit $\mathrm{Balb} / \mathrm{c}$ lupus bunting terhadap perkembangan kadar TNF- $\alpha$. Pemberian ekstra cocor bebek dosis III (42 mg) menghasilkan TNF- $\alpha$ yang paling optimal dalam menurunkan TNF- $\alpha$ dibandingkan dengan pemberian ekstra cocor bebek dosis I (10.5 mg) dan pemberian ekstrak cocor bebek dosis II (21mg).

Tabel 1. Uji Pengaruh Pemberian Ekstrak Cocor Bebek terhadap Kadar TNF-a pada Mencit Balb/c Lupus Bunting

\begin{tabular}{cccccc}
\hline Perlakuan & $\begin{array}{c}\text { Jumlah } \\
\text { Kuadrat }\end{array}$ & db & $\begin{array}{c}\text { Kuadrat } \\
\text { Tengah }\end{array}$ & F & Sig. \\
\hline Ekstrak & 124.595 & 4 & 31.149 & 7.259 & 0.003 \\
Error & 51.490 & 12 & 4.291 & & \\
Total & 176.085 & 16 & & & \\
\hline
\end{tabular}

Berdasarkan tabel 2. diketahui hasil uji statistik $\mathrm{F}$ sebesar 2.761 dengan probabilitas sebesar 0.007. Hal ini dapat diketahui bahwa probabilitas >alpha (5\%), sehingga $\mathrm{H} 0$ diterima. Oleh karena itu, dapat dinyatakan tidak ada perbedaan pengaruh signifikan pemberian ekstrak cocor bebek pada mencit $\mathrm{Balb} / \mathrm{c}$ lupus bunting terhadap perkembangan tekanan darah. 
Tabel 2. Uji Pengaruh Pemberian Eksrak Cocor Bebek terhadap Perkembangan Tekanan Darah pada Mencit Balb/C Lupus Bunting

\begin{tabular}{cccccc}
\hline Perlakuan & $\begin{array}{c}\text { Jumlah } \\
\text { Kuadrat }\end{array}$ & db & $\begin{array}{c}\text { Kuadrat } \\
\text { Tengah }\end{array}$ & F & Sig. \\
\hline Ekstrak & 2427.152 & 4 & 606.788 & 2.761 & 0.077 \\
Error & 2637.083 & 12 & 219.757 & & \\
Total & 5064.235 & 16 & & & \\
\hline
\end{tabular}

Berdasarkan gambar 3 diketahui tidak ada perbedaan pengaruh yang signifikan pemberian ekstrak cocor bebek pada mencit $\mathrm{Balb} / \mathrm{c}$ lupus bunting terhadap albumin urine pada setiap kelompok.

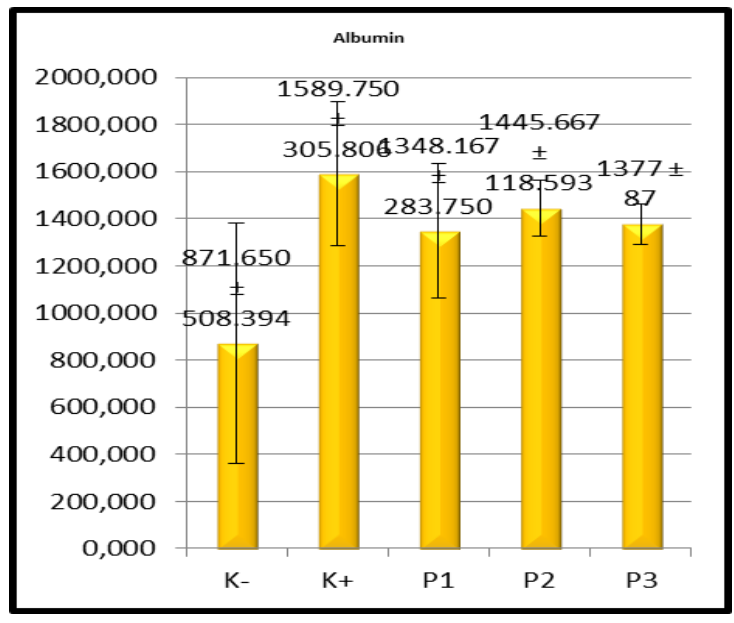

Gambar 3. Rata-Rata Albumin Urine pada Mencit Balb/c Lupus Bunting berdasarkan Pemberian Ekstrak Cocok Bebek

Berdasarkan tabel 3. diketahui tidak ada perbedaan pengaruh yang signifikan pemberian ekstrak cocor bebek pada mencit $\mathrm{Balb} / \mathrm{c}$ lupus bunting terhadap albumin urine pada setiap kelompok perlakuan.

Tabel 3. Pengujian Pengaruh Pemberian Ekstrak Cocor Bebek terhadap Albumin Urine pada Mencit Balb/C Lupus Bunting

\begin{tabular}{cccccc}
\hline Perlakuan & $\begin{array}{c}\text { Jumlah } \\
\text { Kuadrat }\end{array}$ & db & $\begin{array}{c}\text { Kuadrat } \\
\text { Tengah }\end{array}$ & F & Sig. \\
\hline Ekstrak & 1154236.694 & 4 & 288559.173 & 2.748 & 0.78 \\
Error & 1260268.222 & 12 & 105022.352 & & \\
Total & 2414504.915 & 16 & & & \\
\hline
\end{tabular}

PEMBAHASAN

Pengaruh Ekstrak Daun Cocor Bebek Terhadap Kadar TNF-a
Hasil penelitian menunjukkan rerata TNF- $\alpha$ pada kelompok kontrol positif lebih tinggi dibandingkan dengan kelompok negatif. Penelitian yang dilakukan oleh Aringer pada tahun 2014 menyatakan bahwa kadar TNF- $\alpha$ ditemukan meningkat dalam serum pasien dengan LES aktif dan terbukti berkolerasi dengan aktivitas penyakit SLE. TNF- $\alpha$, selain sebagai imunosupresif, juga terlibat dalam kerusakan jaringan organ pada pasien SLE, khususnya lupus nefritis. Tumor Nekrosis Factor-Alpha (TNF- $\alpha$ ) adalah sitokin proinflamasi yang banyak terlibat dalam regulasi kekebalan tubuh (Boos et al,2015).

TN Freceptor1 (TNFR1) TNFR terkait domain kematian fas-associated death domain (FADD) sistem yang mengarah ke sinyal apoptosis, regulasi dwon tradd. Cacat dalam ekspresi genini dapat meningkatkan kemungkinan bahwa limfosit menghindari proses norma yang digunakan oleh sistem kekebalan tubuh untuk menghilangkan limfosit yang diinginkan atau down regulate respon imun.

Hal ini, mungkin mengakibatkan limfosit membebaskan diri dan bertahan hidup sehingga meningkatkan autoimun penyakit. Penelitian Calleja pada tahun 2015 menemukan bahwa TNF- $\alpha$ adalah sitokin yang sangat serbaguna, memainkan peran penting pada apoptosis dan peradangan pada pusat reproduksi. TNF- $\alpha$ disintesis sepanjang saluran reproduksi wanita dalam plasenta dan embrio. TNF- $\alpha$ adalah sitokin pro inflamasi dan terlibat selama perkembangan folikel dan ovulasi, pembentukan korpus luteum dan regresi dan fungsi endometrium.

Pada awal kehamilan hormon rahim ibu yang diatur TNF- $\alpha$ sangat penting untuk invasi trofoblast sedangkan peningkatan TNF$\alpha$ oleh makrofag dapat memfasilitasi terjadinya persalinan. Pemeriksaan TNF- $\alpha$ pada plasenta berdasarkan hasil uji perbandingan berganda dengan uji LSD didapatkan bahwa ada perbedaan pengaruh pemberian ekstrak cocor bebek pada mencit Balb/c lupus bunting terhadap kadar TNF- $\alpha$. Kelompok mencit lupus bunting tanpa pemberian ekstrak cocok bebek menghasilkan TNF- $\alpha$ paling tinggi dan berbeda signifikan dengan kelompok mencit lupus bunting diberi ekstrak cocor bebek dosis $10.5 \mathrm{mg}$ dan kelompok mencit lupus bunting diberi ekstrak cocok bebek $42 \mathrm{mg}$. 
Kelompok mencit lupus bunting diberi ekstrak cocor bebek dosis $42 \mathrm{mg}$ menghasilkan TNF- $\alpha$ paling rendah dan tidak berbeda signifikan dengan kelompok mencit kontrol negatif. Hal ini sejalan dengan hasil penelitian yang dilakukan Nair, dkk yang menyatakan bahwa quercetin yang merupakan senyawa paling aktif dalam flavonoid yang terkandung pada ekstrak cocor bebek mampu menurunkan TNF- $\alpha$ yang merupakan salah satu sitokin proinflamasi yang terlibat dalam patogenesis SLE. Quercetin berada dalam jumlah sekitar $60-75 \%$ dari flavonoid. Penelitian lainnya menunjukkan quercetin dapat menekan tandatanda klinis pada tikus arthritis dengan cara menghambat generasi TNF- $\alpha$ dan nitric oxide (NO) oleh makrofag (Gomalada et al,2005; Matsuda et al, 2014).

Berdasarkan uraian di atas, ekstrak daun cocor bebek mampu menurunkan kadar TNF- $\alpha$ secara signifikan, karena kandungan flavonoid terutama quercetin sebagai senyawa aktifnya mampu memblokir $\mathrm{I} k \mathrm{~B}$ kinase sehingga tidak terjadi degradasi IkB yan dapat mencegah aktifasi dari NF-k $\beta$ yang berfungsi dalam mengontrol ekspresi dari gen yang mengkode sitokin proinflamasi sehingga tidak terjadi peningkatan kadar TNF- $\alpha$.

\section{Pengaruh Ekstrak Daun Cocor Bebek Terhadap Tekanan Darah/MAP Mencit}

Hasil penelitian ini menunjukkan bahwa rerata tekanan darah paling tinggi terdapat pada kelompok mencit bunting lupus tanpa pemberian ekstrak cocor bebek yaitu kelompok kontrol positif. Penelitian yang dilakukan oleh Berg pada tahun 2014 menyatakan bahwa kadar TNF- $\alpha$ yang melebihi kadar normal berhubungan dengan terjadinya peningkatan tekanan darah karena terjadinya disfungsi endotel.

TNF- $\alpha$ menyebabkan terjadinya infeksi dan berperan dalam kerusakan sel endotel. Sel endotel merupakan lapisan sel mempunyai fungsi utama mempertahankan permiabilitas dinding vaskuler. Sel endotel merupakan organ yang dinamis, heterogen, mempunyai fungsi sekresi, sintesis, metabolic dan imunologis (Cines, 2013).

Inflamasi kronik dan aktifasi endotel adalah proses patologis yang berperan pada terjadinya peningkatan tekanan darah. Faktor yang mempengaruhi sitokin proinflamasi ini adalah peran sel endotel, dimana sel endotel ini berperan menjaga keseimbangan sekresi faktor-faktor seperti nitrit oksida, sitokin proinflamasi, agen protrombotik dan faktor antikoagulan. Adanya peningkatan tekanan darah ini merubah sel endotel dan menggangu keseimbangan tersebut (Manabe et al, 2015).

Salah satu faktor potensial yang mengkibatkan tingginya prevalensi terjadinya peningkatan tekanan darah pada pasien LES adalah akibat meningkatnya sitokin proinfalamasi seperti TNF- $\alpha$, IFN-y dan IL-6 yang terlibat dalam patogenesis LES. Hasil penelitian lainnya, melaporkan adanya hubungan langsung antara sirkulasi sitokin inflamasi (TNF- $\alpha$ dan IL-6) dan tekanan darah pada pasien dengan hipertensi. Teori diatas sesuai dengan penelitian ini, dimana ditemukan peningkatan pada sitokin inflamasi yaitu TNF$\alpha$ yang dapat dihubungkan dengan terjadinya peningktana pada tekanan darah mencit Balb/c lupus bunting.

Sekresi TNF- $\alpha$ yang berlebihan akan merusak sel endotel, menyebabkan oklusi pembukuh darah, mengurangi aliran darah regional, dan meningkatkan permeabikitas endothelium. NF-k $\beta$ adalah tanda terjadinya inflamasi. Di nucleus NF-k $\beta$ akan berikatan dengan regio promoter genes yang terlibat dalam respon inflamasi termasuk ICAM, IL-8 dan COX-2. NF-k $\beta$ merupakan konduktor regulasi sitokine yang berperan pada terjadinya peningkatan tekanan darah (Shah, 2015).

Berdasarkan hasil penelitian, ekstrak daun cocor bebek mampu menurunkan kadar TNF- $\alpha$ dengan cara menekan sitokin proinflamasi seperti TNF- $\alpha$, maka penurunan tekanan darah yang ditemukan pada mencit bunting dengan LES dihubungkan dengan penurunan sitokin proinflamasi seperti TNF- $\alpha$ melalui pemberian ekstrak daun cocor bebek. Namun,pemberian ekstrak daun cocor bebek dengan dosis $10.5 \mathrm{mg} / \mathrm{hari}, 21 \mathrm{mg} / \mathrm{hari}$, dan 42 $\mathrm{mg} /$ hari belum mampu menurunkan tekanan darah secara signifikan.

\section{Pengaruh Ekstrak Daun Cocor Bebek Terhadap Albumin Urine Mencit}

Hasil penelitian diperoleh hasil kadar albumin urine pada kelompok kontrol positif lebih tinggi secara signifikan dibandingkan dengan kelompok kontrol negatif, penelitian sejalan dengan hasil penelitian yang dilakukan oleh Satoh pada tahun 2016 yang menemukan bahwa mencit Balb/c yang diinjeksi Pristan 
secara intraperitoneal tidak hanya menunjukkan peningkatan autoantibodi tetapi juga peningkatan protein urine signifikan. Selain itu, pemeriksaan menggunakan mikroskop cahaya pada ginjal menunjukkan adanya deposit kompleks imun subepitel dan mesangial dan hasil imunofluoresen juga menunjukkan adanya penumpukan dari IgM, $\mathrm{IgD}$, dan $\mathrm{C} 3$ pada glomerulus.

Keluarnya albumin melalui urine diakibatkab oleh peningkatan permeabilitas di tingkat glomerulus yang menyebabkan protein lolos ke dalam filtrat glomerulus. Konsentrasi protein ini melebihi kemampuan sel-sel tubulus ginjal mereabsopsi dan memprosesnya.

Berdasarkan uraian diatas, pemberian ekstrak daun cocor bebek menunjukkan penurunan pada albumin urin namun, penurunan tersebut tidak signifikan. Penurunan ini kemungkinan akibat kemampuan ekstrak daun cocor bebek dalam menurunkan persentase sel TNF- $\alpha$ yang berhubungan dengan proses inflamasi yang terjadi pada ginjal tidak hanya melibatkan sitokin Th1, namun sitokin proinflamasi lainnya seperti Th17, IL-17, IL-23 dan IL-6 berperan dalam proses inflamasi pada ginjal. Disisi lain, dosis ekstrak daun cocor bebek 10,5 mg/hari, 21 $\mathrm{mg} /$ hari dan $42 \mathrm{mg} /$ hari yang diberikan belum mampu memperbaiki kerusakan ginjal pada mencit lupus bunting.

\section{KESIMPULAN}

Pengaruh ekstrak daun cocor bebek terhadap tekanan darah mencit dengan hasil ekstrak daun cocok bebek mampu memurunkan kadar TNF- $\alpha$ secara signifikan karena kandungan flavonoid terutama quercetin sebagai senyawa aktifnya mampu memblokir Ik $\beta$ kinase sehingga tidak terjadi degdradasi Ik $\beta$ yang berfungsi dalam mengontrolkan eskpresi dari gen yang mengkode sitokin proinflamasi sehingga tidak terjadi peningkatan kadar TNF- $\alpha$. Sementara untuk penurunan ablumin urine mencit, pemberian daun cocor bebek menurunkan albumin urine namun, penurunan tersebut tidak signifikan. Jadi dapat disimpulkan, ekstrak daun cocor bebek mampu menurunkan kadar TNF- $\alpha$ secara signifikan, tetapi ekstrak daun cocor bebek tidak mampu menurunkan kadar albumin urien dan tekanan darah.

Sampai saat ini, obat untuk penyakit LES masih terbatas pada obat-obat sintentik, daun cocor bebek dapat dijadikan alternatif pengobatan herbal untuk penyakit LES dengan cara diolah menjadi ekstra. Kita tidak selalu bergantung pada obat-obatan yang ketersediannya terbatas, daun cocor bebek tergolong tanaman yang mudah ditemukan dan mudah untuk ditanam.

\section{UCAPAN TERIMA KASIH}

Peneliti sangat berterima kasih kepada LPPT Universitas Islam Negeri (UIN) yang telah menyediakan hewan mencit sebagai bahan percobaan pada penelitian ini dan peneliti berterima kasih juga kepada Universitas Brawijaya Malang (UB) yang telah memfasilitasi selama proses penelitian ini baik dari awal pengambilan data, proses eksperimen sampai selesainya penelitian ini.

\section{DAFTAR PUSTAKA}

Aringer, M., \& Smolen, J. S. (2014). Complex Cytokine Effects in a Complex Autoimmune Disease Tumor Necrosis Factor in System Lupus Erythematosus. Arthritis Research and Therapy, 5(4), 172-177.

Baratawidjaja. K. G dan Rengganis. I. (2014). Imunologi Dasar. Edisi ke sebelas. Fakultas Kedokteran Universitas Indonesia. Jakarta.

Berg, A and Scherer, P. (2014). Adipose Tissue, Inflamation, and Cardiovascular Disease.Journal of American Heart Asociation, 21(12): 1873-1879.

Boos, Christopher J. and Gregory Y. H. Lip. (2015). Is Hypertension and Inflamatory Process Current Pharmaceutical Design, $12,1623-1635$.

Calleja-Agius, J., Muttukrishna, S., \& Jauniaux, E. (2015). Role of TNF- $\alpha$ in Human Female Reproduction.

Chae, C. U., Lee, R. T., Rifai, N., \& Ridker, P. M. (2012). Blood Pressure and Inflammation in Apparently Healthy Men. Hypertension, 38(3), 399-403.

Cines, D. B., Pollak, E. S., Buck, C. A., Loscalzo, J., Zimmerman, G. A., McEver, R. P., \& Barmathan, E. S. (2013). Endothelial Cells in Physiology and in The Pathophysiology of Vascular Disorders. Blood, 91(10), 3527-3561.

Kelley, V. R., \& Wuthrich, R. P. (2014). Cytokines in The Pathogenesis of Systemic Lupus Erythematosus. In 
Seminar in Nephrology (Vol. 19, No.1, pp.57-66).

Kim, S., \& Iwao, H. (2012). Molecular and Cellular Mechanisms of Angiotensin IIMediated Cardiovascular and Renal Diseases. Pharmacological Reviews, 52 (1), 11-34.

Manabe, S., Okura, T., Watanabe, S., Fukuoka,T., \& Higaki, J. (2015). Effects of Angiotensin II Receptor Blockade with Valsartan On Pro-Inflammatory Cytokines in Patiens with essential hypertension. Journal of Cardiovascular Pharmacology, 46(6), 735-739.

Miyake, K., Akahoshi, M., Nakasihma, H., (2011). The Subset Balance in Lupus Nephritis. Biomed Research International.

Nair, M., Mahajan, S., Reynolds, J., Aalinkeel, R., Nair, H., Schwartz, S and Kandaswami, C. (2013). The Flavonoid Quercetin Inhibits Proinflammatory Cytokine (Tumor Necrosis Factor Alpha) Gene Expression in Normal Peripheral Blood Mononuclear Cell via Modulation of The NF- $k \beta$ System. Clinical and Vaccine Immunology, 13 (3): 319-328.

Ryan, M. J., Mc Lemore, G. R., Hendrix, S. T. (2015). Insulin Resistance and Obesity in a Mouse Model of Systemic Lupus Erythematosus. Hypertension. 48(5): 988-993.

Savoia, C., \& Schiffrin, E. L. (2015). Inflammation in Hypertension. Current Opinion in Nephrology and Hypertension, 15(2), 152-158.

Sturgis, L. C., \& Brands, M. W. (2013). Role of TNF- $\alpha$ in The Dependency of Angiotensin II Hypertension on IL6.The FASEB Journal, 21 (5), A590.

Sumariyono. (2013). Spektrum Autoantibodi Pada LES dan Hubungannya Dengan Gambaran Klinik. In; Setiyohadi B, Kasjmir YI, editors. Naskah Lengkap Temu Ilmiah Reumatologi ASEAN meeting on Gout and Hyperuricemia. Jakarta: EGC; p.149-153.

Varghese Stephy, Crocker Ian, Bruce N Ian \& Tower Clare. (2015). Systemic Lupus Erythematosus Regulatory T Cells and Pregnancy. From www.expertreviews.com/toc/eci/7/5.

Yu, E. S., Min, H.J., An, S.Y., Won, H.Y., Hong, J. H., \& Hwang, E. S. (2014). Regulatory Mechanisms of IL-2 and IFN $\gamma$ Suppression by Quercetin in Thelper Cells. Biochemical Pharmacology, 76(1), 70-78. 